Community: Volume 4, Nomor 2, Oktober 2018

ISSN: 2477-5746 e-ISSN: 2502-0544

\title{
PERGESERAN POLA INTERAKSI WARUNG KOPI PADA MASYARAKAT ACEH BARAT
}

\author{
Mursyidin \\ Program Studi Sosiologi FISIP Universitas Teuku Umar \\ Mursyidin@utu.ac.id
}

\begin{abstract}
This article intends to examine how changes in the patterns of social interaction in coffee shops occur, how they change and what factors cause change. Data were obtained from the results of observations and literature studies which were then analyzed using a qualitative approach with descriptive analytical methods. The results of this study indicate that the development of digital technology, globalization and cultural contact that occur through digital media has influenced the patterns of interaction between Acehnese people in coffee shops, especially in young people. The interaction in the coffee shop changes from an interaction / verbal communication model to a virtual interaction. Besides that the function of the coffee shop has also changed, now the coffee shop is no longer a space for discussion and interaction but is a symbol of the lifestyle of young people and at the same time a "workplace" or new office for the community.
\end{abstract}

Keywords: Interaction, Warung Kopi, Social Change

\section{PENDAHULUAN}

Interaksi sosial antar manusia selalu mengalami perubahan, terlebih di zaman globalisasi saat ini manusia dapat memperoleh informasi dengan cepat dari berbagai penjuru dan mengenal batas ruang dan waktu. Informasi dapat diperoleh dengan cepat dalam waktu yang singkat selama manusia memiliki perangkat teknologi informasi seperti televisi, internet dan smartphone. Globalisasi dan perkembangan teknologi informasi membuat seluruh masyarakat dunia mampu mengenal karakteristik dan kebudayaan di seluruh dunia secara luas, meskipun penggunaan bahasa dalam proses interaksi masyarakat global saat ini tentunya menggunakan bahasa universal dan dapat dimengerti oleh sebagian besar masyarakat dunia.

Perkembangan globalisasi masa kini telah mengalami kemajuan yang sangat pesat, hal ini terbukti dengan adanya globalisasi ekonomi, teknologi, informasi, politik budaya, dan lain sebagainya yang dirasakan oleh masyarakat (Piliang, 2010 : 236). Globalisasi dan persaingan global membuat penggunaan bahasa tradisional dalam interaksi sedikit demi sedikit menjadi luntur, karena globalisasi memiliki kata kunci 
Community: Volume 4, Nomor 2, Oktober 2018

ISSN: 2477-5746 e-ISSN: 2502-0544

dalam proses interaksi yang lebih menuntut penggunaan bahasa yang simpel dan mudah dipahami oleh masyarakat dengan berbagai latar belakang suku yang berbeda-beda. Proses interaksi global saat ini bisa terjadi dimana saja tidak mengenal ruang dan waktu, bisa melalui penggunaan media dan berbagai macam tempat yang memungkinkan masyarakat dari berbagai macam latar belakang yang beragam untuk melakukan interaksi secara berkelanjutan khususnya di ruang publik seperti taman, sekolah, pusat perkantoran, pusat perbelanjaan restoran hingga ke warung kopi.

Dari sudut pandang budaya, warung kopi sebagian besar berfungsi sebagai pusat interaksi sosial yang menyediakan sebuah tempat untuk berkumpul, berbicara, menulis, membaca, menghibur satu sama lain, atau melewatkan waktu, baik secara individu atau dalam kelompok kecil anggota sosial tersebut. Bagi masyarakat modern, singgah di warung kopi sudah menjadi keharusan dan kebiasaan. Untuk sekedar bersantai atau mencari variasi hiburan ditengah rutinitas yang padat, duduk sebentar dan minum secangkir kopi menjadi kenikmatan tersendiri. Berbincang dengan relasi terasa lebih rileks dan hangat(Said, 2017).

Hadirnya warung kopi menjawab kebutuhan akan sebuah ruang yang bisa digunakan untuk bertemu kawan berdiskusi atau memperbincangkan berbagai hal dengan cukup ditemani secangkir minuman favorit dalam suasana yang nyaman. Warung kopi bisa saja dianggap sebagai Kafe bagi mereka yang hidup dalam budaya urban perkotaan modern. Meski fungsinya sama, yakni tempat di mana orang bisa minum (kopi) sambil bercakap-cakap, tetapi kafe berada dalam pemaknaan budaya yang berbeda. yang karena itu pemaknaan kulturalnya berbeda dengan warung kopi dalam masyarakat tradisional (Said, 2014). Warung kopi telah menjadi fenomena menarik di sejumlah kota besar seperti terutama di Aceh.

Warung kopi, telah menjadi simbol budaya, sekaligus identitas kolektif masyarakat Aceh. Tak berlebihan, jika harian Kompas (2011) penah menulis "Aceh Negeri 1001 Warung Kopi," untuk menegaskan vitalnya keberadaan warung kopi di sana (Al-Fairusy, 2014). Perkembangan warung kopi di Aceh, terus mengarah pada terminologi ruang publik, pertemuan, negosiasi, hingga tak jarang digunakan untuk kepentingan politik (seperti kampanye). Eksistensi warung kopi di Aceh, yang boleh digunakan dan diakses oleh siapapun, tanpa tekanan dan marginalisasi status-siapapun dapat berkunjung, bahkan perempuan pun (dari kajian feminis dan gender), memiliki tempat untuk berkumpul bersama kaum laki-laki. Meskipun, pada awal pertumbuhan warung kopi, kehadiran perempuan di warung kopi memiliki stigma dan tabu dalam kacamata masyarakat Aceh.

Berdasarkan deskripsi di atas dapat dipahami bahwa kehadiran warung kopi menjadi ruang publik bagi masyarakat yakni tempat diskusi dan berinteraksi secara verbal dan tatap muka. Tetapi Kini (2018) eksistensi warung kopi sebagai medium ruang interaksi verbal mengalami pergeseran, terutama dikalangan kaum muda. Warung 
Community: Volume 4, Nomor 2, Oktober 2018

ISSN: 2477-5746 e-ISSN: 2502-0544

kopi kini tidak lagi menjadi medium ruang publik dimana interaksi sosial, pertukaran informasi, diskusi-diskusi terjadi secara masif, teapi kita dapat menyaksikan warung kopi "hanya" menjadi tempat minum kopi, buka tempat berinteraksi karena masingmasing individu telah disibukkan dengan perangkat teknologi yang ada di tangan mereka masing-masing sedangkan interaksi verbal hanya terjadi sesekali saja. Realitas ini tentunya menunjukkan sebuah perubahan pola interaksi yang terjadi pada warung kopi di Aceh terutama para kaum muda, untuk itu tulisan ini bermaksud mengkaji bagaimana perubahan pola interaksi sosial di warung kopi terjadi, bagaimana bentuk perubahannya dan apa saja faktor yang menyebabkan perubahan itu.

\section{TINJAUAN PUSTAKA}

\section{Perubahan Sosial dan Globalisasi}

Perubahan sosial merupakan perubahan kehidupan masyarakat yang berlangsung terus-menerus dan tidak akan pernah berhenti, karena tidak ada satu masyarakatpun yang berhenti pada suatu titik tertentu sepanjang masa. Manusia memiliki peran sangat penting terhadap terjadinya perubahan masyarakat. Perubahan itu terjadi sesuai dengan hakikat dan sifat dasar manusia yang selalu ingin melakukan perubahan, karena manusia memiliki sifat selalu tidak puas terhadap apa yang telah dicapainya, ingin mencari sesuatu yang baru untuk mengubah keadaan agar menjadi lebih baik sesuai dengan kebutuhannya. Manusia sebagai mahluk Tuhan, dibekali akal-budi untuk memenuhi kebutuhannya. Kelebihan manusia terletak pada akal-budi tersebut, yakni sebagai potensi dalam diri manusia yang tidak dimiliki oleh mahluk lain. Akal merupakan kemampuan berpikir.

Kemampuan berpikir digunakan oleh manusia untuk memecahkan masalah masalah hidup yang dihadapinya. Budi merupakan bagian dari kata hati, berupa paduan akal dan perasaan, yang dapat membedakan antara baik dan buruk sesuatu. Dengan berbekal akal-budi tersebut manusia memiliki tujuh kemampuan yang berfungsi untuk: menciptakan, mengkreasi, memperlakukan, memperbarui, memperbaiki, mengembangkan, dan meningkatkan segala hal dalam interaksinya dengan alam maupun manusia lainnya (Herimanto dan Winarno, 2009). Kebudayaan yang dihasilkan melalui akal budi manusia sering menjadi pencetus terjadinya perubahan sosial. Artinya perubahan sosial tidak terlepas dari perubahan kebudayaan. Bahkan Kingsley Davis (Soerjono Soekanto, 2000) berpendapat bahwa perubahan sosial merupakan bagian dari perubahan kebudayaan.

Perubahan sosial sangat erat kaitannya dengan globalisasi. Istilah globalisasi sering diberi arti yang berbeda antara yang satu dengan yang lainnya, sehingga disini perlu penegasan lebih dulu. Ahmed dan Doman (Azizy, 2004: 19) memberi batasan bahwa Globalisasi pada prinsipnya mengacu pada perkembangan-perkembangan yang cepat di dalam teknologi komunikasi, transfortasi, yang bisa membawa bagian-bagian 
Community: Volume 4, Nomor 2, Oktober 2018

ISSN: 2477-5746 e-ISSN: 2502-0544

dunia yang jauh (menjadi hal-hal) yang bisa dijangkau dengan mudah. Dalam globalisasi, media massa dan teknologi digital telah mengubah dunia menjadi sebuah dusun global (global village). Informasi dan gambar peristiwa yang terjadi di tempat yang sangat jauh dapat ditonton jutaan orang pada waktu bersamaan. Menurut Martono (2011: 96) Globalisasi dapat didefinisikan sebagai penyebaran kebiasaankebiasaan yang mendunia, ekspansi hubungan yang melintasi benua, organisasi kehidupan sosial pada skala global, dan pertumbuhan sebuah kesadaran global bersama. Sedangkan menurut Azazy (2004: 20) mengemukakan bahwa Dalam era globalisasi ini berarti terjadi pertemuaan dan gesekan nilai-nilai budaya dan agama di seluruh dunia yang memanfaankan jasa komunikasi, transfortasi, dan informasi hasil modernisasi teknologi tersebut.

Dari pengertian di atas, dapat disimpulkan bahwa globalisasi merupakan proses penyebarab kebiasaan-kebiasaan yang mendunia, yang pada prinsipnya mengacu pada perkembangan yang cepat di dalam teknologi komunikasi dan informasi yang bisa menghubungkan tempat-tempat yang jauh menjadi dekat dan dapat membawa pengaruh terhadap pergesekan nilai atau pertukaran budaya baik disengaja maupun tidak yang dapat memberikan pengaruh kepada sikap dan perilaku manusia dalam suatu bangsa.

\section{METODE PENELITIAN}

Penelitian ini merupakan penelitian dengan pendekatan deskriptif kualitatif. Metode penelitian kualitatif digunakan karena metode ini mampu menganalisa realitas sosial secara mendalam. Metode kualitatif dapat digunakan untuk mempelajari, membuka, dan mengerti apa yang terjadi dibelakang setiap fenomena yang baru.

Penelitian ini lebih difokuskan pada penelitian lapangan (field research) yang dimaksud untuk mengetahui permasalahan dan untuk mendapatkan informasi-informasi serta data yang ada di lokasi penelitian. Sumber data yang digunakan dalam penelitian ini adalah sumber data yang diperoleh dari hasil observasi partisipatoris serta penelaahan kepustakaan (library study) dan kemudian dianalisis dengan menggunakan pendekatan kualitatif.

\section{HASIL DAN PEMBAHASAN}

Warung kopi di Aceh memiliki sejarah dan konteks sosial yang berbeda dengan warung-warung kopi di luar Aceh. Konflik yang melanda Aceh sejak masa belanda hingga penandatangan MOU Helsinki memberikan pengaruh tersendiri terhadap prosesproses sosial yang terjadi pada masyarakat Aceh hingga ke warung kopi. Dari warung kopi, rakyat Aceh menyusun strategi perang untuk menghadapi dan mengalahkan Belanda. Karena itu, pada saat kolonialisme berlangsung, Belanda ikut memantau 
Community: Volume 4, Nomor 2, Oktober 2018

ISSN: 2477-5746 e-ISSN: 2502-0544

segala aktivitas yang berkembang di warung kopi. Demikian, kira-kira yang dipaparkan Mauriza, dalam skripsinya "Fungsi Warung Kopi bagi Masyarakat Aceh"(Al-fairuzy, 2014).

Tak hanya itu, lebih spesifik, Mauriza menyebut bahwa ragam fungsi warung kopi di Aceh, dan mendeskripsikan studi komprasi antar-warung kopi di setiap negara. Keberadaan warung kopi di Manila misalnya, yang menjadi tempat untuk berbagi cerita, bertukar pikiran, gosip, sampai kepada berbicara masalah politik oleh konsumennya. Kondisi di Manila, tentu serupa di Aceh, kedai kopi juga digunakan oleh masyarakat Aceh sebagai tempat berinteraksi satu sama lain, saling bercerita, bertukar pikiran, hingga merambah ranah politik. Bedanya, kedai kopi di Manila ada yang berbentuk eksklusif, yang dikhususkan untuk kalangan tertentu. Golongan ekslusif di Manila memiliki kartu anggota, bagi setiap orang yang ingin masuk ke warung kopi. Namun, di Aceh tidak berlaku card member, karena kedai kopi di Aceh terbuka untuk masyarakat secara egaliter, tidak dikhususkan pada golongan tertentu (Mauriza dalam Al-Fairusy, 2014).

Eksistensi warung kopi di Aceh menjelma menjadi ruang publik yang memiliki akar sejarah dalam diri masyarakat Aceh itu sendiri, sehingga tidak heran apabila kita mendapai fenomena bahwa disetiap warung kopi yang ada di Aceh selalu dipenuhi oleh pengunjung. Bahkan cukup sulit menemukan warung kopi yang tidak ada pengunjungnya. Beberapa literatur menunjukkan bahwa warung kopi di Aceh beberapa tahun terakhir telah menjadi ruang artikulasi baru bagi masyarakat Aceh untuk berekpresi dan berinteraksi, bahkan tak jarang kita menumukan diskusi yang cukup menarik disetiap pojok-pojok warung kopi di Aceh.

Tetapi seiring waktu realitas ini tampak muali bergeser. Interaksi sosial yang masif diwarung kopi sayup-sayup mulai menghilang dan hanya terdengar sesekali saja, terlebih pada warung kopi yang di dominasi oleh kaum muda. Kita akan menemukan realitas yang cukup kontras dengan fenomena warung kopi di Aceh beberapa tahun kebelakang. "Telah terjadi perubahan pola interaksi di warung kopi", itu adalah kata yang tidak bisa dipungkiri. Kini dimanapun kita kunjungi warung kopi kita akan lebih banyak melihat fenomena interaksi diwarung kopi yang kian menyusut. Orang lebih banyak terapaku pada "barang" teknologi yang ada ditanganya dari pada berinteraksi dengan teman sebangkunya di warung kopi.

\section{Perubahan Pola Interaksi Sosial di Warung Kopi}

Disadari atau tidak, diakui ataupun tidak, perubahan pola interaksi sosial di warung kopi sesungguhnya benar-benar sudah terjadi. Persentuhan budaya yang terjadi pada masyarakat Aceh yang dilatar belakangi oleh keterbukaan informasi dan teknologi hari ini merupakan aspek penting dalam memahami perubahan pola interaksi masyarakat di warung kopi. Lihat saja misalnya poto yang penulis ambil ketika melakukan observasi di beberapa warung kopi yang ada di Aceh seperti di bawah ini; 

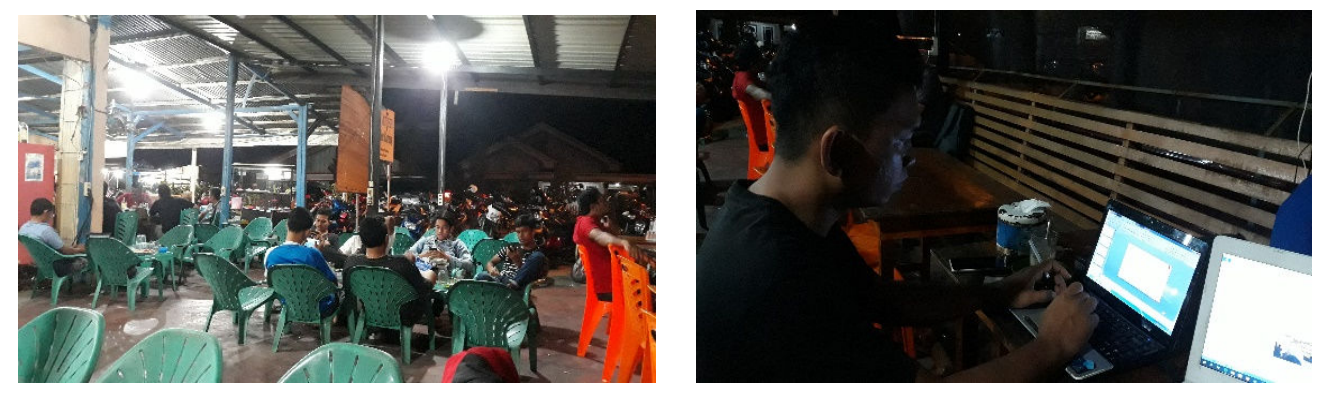

Gambar 1.

Pola interaksi masyarakat di warung kopi

Gambar di atas merupakan fenomena yang akan kita jumpai di banyak warung kopi yang ada di Aceh. Fenomena ini tentu berbeda dengan realitas warung kopi beberapa tahun yang lalu ketika media sosial seperti WA atau youtube bisa di akses dengan mudah, ditambah lagi dengan kuota internet dan fasilitas wi-fi yang begitu mudah. Akibatnya meskipun pengunjung warung kopi datang dan duduk bersama satu meja tetapi interaksi sosial tidak terjadi dengan baik, apalagi diskusi-diskusi yang kostruktif seperti masa pada masa lalu.

Warung Kopi yang dulunya sebagai tempat obrolan mengasyikan kini perlahan mulai hilang dari peradaban. Kebiasaan menyapa dan mengajak lawan untuk berbicara sekalipun tidak mengenal sebelumnya mulai ditinggal manusia. Sekarang, mereka lebih "mencintai" alat komunikasi yang sudah terhubung dengan wi-fi dari pada berkenalan, menyapa atau mengajak berbicara orang yang ada di sebelahnya. Mereka lebih berinisiatif untuk bertanya password wi-fi kepada penjaga warung dari pada mengajak ngobrol sesamanya. Manusia-manusia di warung kopi jaman sekarang (tak terbatas umur dan jenis kelamin) tanpa disadari jika kita terus mempertahankan bahwa teknologi adalah segala-galanya dan tanpa wifi serta gadget hidup kurang nyaman, bahkan dalam beberapa istilah disebutkan bahwa your life in your hand.

Perubahan pola interaksi yang paling jelas nampak di warung kopi adalah perubahan dari interaksi verbal, komuikasi dua arah yang intensif dan bersifat diskursif menjadi komunikasi dan interaksi semu, virtual, dan intensitasnya berkurang. Diskusidiskusi mulai jarang terjadi diwarung kopi tetapi berganti jadi tempat main game dengan fasilitas wifi yang memanjakan sehingga pengunjung sibuk dengan teknologi yang ada di tanganya lalu lupa saling menyapa antar sesama mereka.

Beberapa faktor yang mempengaruhi perubahan pola interaksi di warung kopi sejalan dengan asumsi-asusmi teoritik yang dikemukakan oleh beberapa pakar teori perubahan sosial yang menyatakan bahwa perubahan sosial akan terjadi apabila masyarakat mulai terbuka dengan perubahan-perubahan baru, persentuhan yang terjadi dengan budaya lain, penemuan dan perubahan pada aspek teknologi dan juga 
Community: Volume 4, Nomor 2, Oktober 2018

ISSN: 2477-5746 e-ISSN: 2502-0544

berubahnya struktur sosial dalam masyarakat. Fenomena perubahan pola interaksi di warung kopi bisa di indetifkasi dari realitas masyarakat Aceh pasca tsunami dimana masyarakat Aceh mulai bersentuhan dengan budaya lain dan masyarakat Aceh semakin terbuka terhadap budaya luar sehingga terjadi penyerapan nilai-nilai baru dalam masyarakat akibat pertemuan budaya. Perubahan teknologi menjadi salah satu aspek yang juga fundamental dalam perubahan pola interaksi masyarakat karena dengan perkembangan teknologi digitas dan globalisasi manusia sudah kehilangan sekatsekatanya secara sosial sehingga bisa terhubung dengan sipapun dalam waktu yang singkat.

Akibatnya, individu-individu lebih suka berselancar di dunia maya dan saling berinteraksi di dunia virtual itu daripada berinteraksi di dunia nyanta. Kesenangan tersebut menjadi fenomena baru dan karena pada ruang-ruang virtual apapun dapat di ekspresikan dan sangar minim kontrol. Kesenangan ini kemudian di fasilitasi dengan baik oleh perkembangan warung kopi yang ada di Aceh pada saat ini. Hampir setiap warung kopi memiliki perangkat teknologi seperti TV dan akses intenet sehingga memudahkan pengunjung untuk mengakses dunia luar melalui teknologi yang di tangan mereka masing-masing. Kehadiran warung kopi selaras dengan perkembangan teknologi yang maju sehingga kesenangan yang timbul akibat perubahan teknologi mendapatkan wadah artikulasinya dengan maraknya warung kopi di Aceh sehingga secara otomatis pasti akan mengubah pola interaksi yang terjadi diwarung kopi.

\section{Warung Kopi; Simbol Gaya Hidup}

Sebagaimana bisnis lain yang menggunakan strategi gaya hidup, warung-warung kopi di Aceh juga memperdagangkan "simbol". Secangkir kopi mungkin menjadi perangkat simbol tertentu. Kopi tidak sebatas berfungsi menjadi penghilang kantuk, teman begadang nonton bola, namun telah berubah menjadi sebagai kode simbolik yang digunakan sebagian kalangan peminumnya untuk mengkomunikasikan, mencitrakan, mengaktualisasikan keberadaan mereka dalam kelompok sosial. Komodifikasi kopi tampaknya berjalan beriringan dengan komodifikasi gaya hidup. Banyak bisnis warung kopi mencoba merumuskan dirinya dalam bisnis di jaman kontemporer yang penuh dengan berbagai jargon-jargon simbolik seperti nikmatnya kemewahan, menciptakan tempat dimana pelanggan dapat relaks, dan sebagainya.

Kopi memang telah mengubah cara berinteraksi banyak orang saat ini. Kopi dipandang sebagai pendamping dalam mengobrol dan nongkrong, mendekatkan ikatan persahabatan, menghangatkan suasana, dan lain sebagainya. Namun fenomena tersebut adalah kenyataan yang dibangun oleh media digital untuk meningkatkan penjualan produknya. Tentunya nilai tambah perlu disuguhkan dalam mengiklankan dan memasarkan produk kopi ini, salah satunya adalah dengan menggunakan image kopi sebagai pendamping saat mengobrol, berkiblat pada budaya barat yang terbiasa minum 
kopi di café, warung kopi atau bar saat berkumpul bersama sahabat dan teman. Akhirnya kopi dijadikan simbol dari sebuah gaya hidup masyarakat urban yang dimanfaatkan sebagai komoditas yang menguntungkan. Bahkan mungkin kita pernah mendengar sebuah pernyataan bahwa ngumpul gak aysik tanpa ngopi bareng.

\section{Warung Kopi Sebagai Ruang Kerja Baru}

Fasilitas free Wi-Fi yang tersedia di warung kopi ini menjadi nilai tambah dan nilai jual untuk menarik konsumen berkunjung kewarung kopi. Sebagain orang berkunjung ke warung-warung kopi saat ini bukan untuk berinteraksi dan bersosialisasi tetapi ingin memanfaatkan fasilitas internet disana. Bahkan bagi sebagian orang, fasilitas internet gratis yang disediakan oleh warung kopi berdampak pada aktivitas interpersonal dan jaringan sosial mereka serta bagi sebagian orang lainnya justru turut memberi andil bagi munculnya nilai privatisme, yakni kecenderungan dimana orangorang lebih memilih menghabiskan waktunya di warung kopi dari pada di rumah.

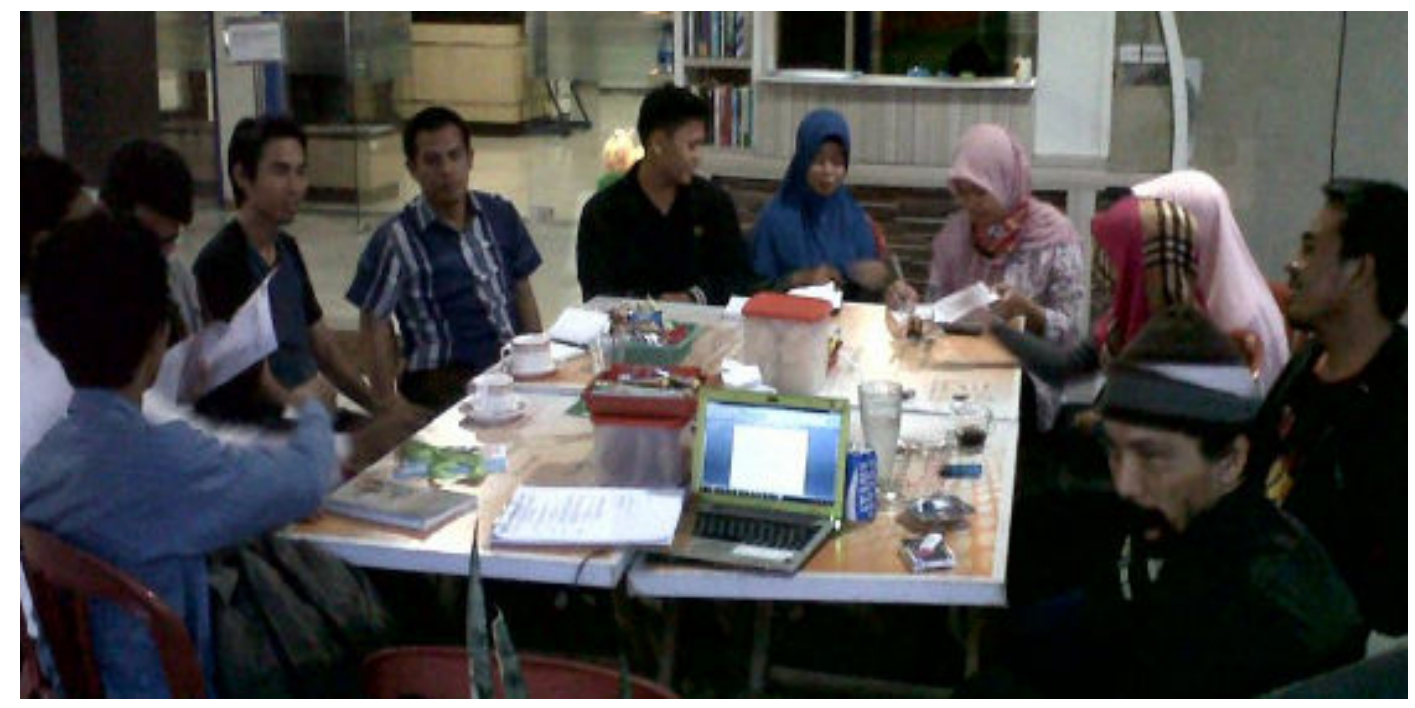

Gambar 2:

Membahas pekerjaan di warung kopi

Lihat saja foto di atas misalnya, warung kopi telah mengubah makna dan persepsi masyarakat tentang warung kopi itu sendiri. Perkembangan media digital telah membuat warung kopi menjadi tempat kerja baru bagi masyarakat. Banyak kita temukan orang-orang lebih asik mengerjakan pekerjaannya diwarung kopi dari pada dirumah atau diperpustakaan misalnya. Tentu hal yang kontras akan kita temukan dimana perpustakaan tidak lagi menjadi tempat yang asik untuk mengerjakan tugas bagi pelajar dan mahasiswa, mereka lebih suka mengerjakannya diwarung kopi. Bahkan 
Community: Volume 4, Nomor 2, Oktober 2018

ISSN: 2477-5746 e-ISSN: 2502-0544

tidak jarang kita menemukan seorang mahasiswa asik dengan laptopnya seorang diri di warung kopi mengerjakan tugas kuliah, atau seorang pekerja menyelesaikan laporan dengan duduk diwarung kopi seorang diri. Hal ini terjadi disebabkan oleh perkembangan teknologi digital yang begitu massif, akibat lainnya adalah kita akan menemukan interaksi sosial diwarung kopi juga ikut berubah, bahkan seringkali kita menemukan warung kopi yang senyap tanpa ada interaksi di dalamnya karena kesibukan dengan pekerjaan masing-masing yang mereka bawa ke warung kopi.

\section{KESIMPULAN}

Perkembangan media massa dan teknologi digital dewasa ini merupakan ekses atau dampak dari globalisasi dan modernisasi yang kemudian turut memberikan pengaruh pada pola interaksi yang terjadi diwarung kopi. Pada saat ini, fenomena orang duduk diwarung kopi sudah berubah, demikian pula dengan pola interaksinya. Beberapa tahun terakhir sebelum teknologi digital berkembang begitu pesat kita masih mudah menemukan diskusi-diskusi, interaksi antar individu diwarung kopi terjadi demikian massif. Tetapi hari ini, interaksi tersebut mulai menurun digantikan komunikasi virtual melalui teknonogi digital. Perubahan ini terjadi tidak terlepas dari pengaruh digital itu sendiri, orang-orang yang duduk di warung kopi tidak lagi berinteraksi secara verbal, diskusi-diskusi jarang dilakukan karena masing-masing asik dengan teknologi yang ada di tangan masing-masing.

Selain itu, warung kopi juga tidak lagi menjadi ruang publik sebagai medium komunikasi tetapi berubah fungsi menjadi simbol gaya hidup yang terus menerus diproduksi oleh teknologi digital, akibatnya orang kewarung kopi tidak hanya untuk meminum kopi tetapi untuk menunjukkan eksistensinya sebagai manusi modern. Dan hal ini di fasilitiasi dengan baik oleh berbagai fasilitas dan inovasi yang dilakukan oleh warung kopi itu sendiri, yaitu dengan memberikan fasilitas internet, mengubah nama warung kopi menjadi kafe dan lain sebagainya. Dampak lainnya dari berubahnya pola interaksi dan fungsi warung kopi adalah alih fungsi warung kopu dari tempat minum kopi dan ruang interaksi menjadi tempat kerja baru. Akibatnya interaksi dan komunikasi menjadi semakin terdistorsi karena orang kewarung kopi bukan untuk minum kopi tapi untuk bekerja sambil menikmati internet gratis.

\section{DAFTAR PUSTAKA}

Ardietya Kurniawan dan Muh Rosyid Ridlo, Perilaku Konsumtif Remaja Penikmat Warung Kopi , Jurnal Sosiologi DILEMA, Vol. 32, No. 1 Tahun 2017

Herimanto dan Winarno, Ilmu Sosial \& Budaya Dasar, Jakarta : PT.Bumi. Aksara, 2010 
Community: Volume 4, Nomor 2, Oktober 2018

ISSN: 2477-5746 e-ISSN: 2502-0544

Irwanti Said, Warung Kopi dan Gya Hidup Modern, Jurnal Al-Khitabah, Volume III No 1 Juni 2017

Kompas. 2011. Aceh: Negeri 1001 Warung Kopi

Muhajir Al Fairusy, Public Sphere In a Cup of Coffee" Telescoped public sphere and discourse production in Aceh coffee shop, 2014

--------------------, Warung Kopi di Medan Pilkada. Jurnal online Aceh Institute, 2008

Nanang Maertono, Metode Penelitian Kuantitatif. Jakarta: PT Raya. Grafindo Persada, 2010

Piotr Sztompka, Sosiologi Perubahan Sosial, Cet. Ke-3. Jakarta: Prenada, 2007

Rani Sartika, Pergeseran Budaya Ngopi Di Kalangan Generasi Muda Di Kota Tanjungpinang, Jurnal Umrah, 2017

Soerjono Soekanto, Sosiologi Suatu Pengantar, Jakarta: PT Raja Grafindo, 2010 